\title{
OBSERVAÇÕES PRELIMINARES SÔBRE IRRIGAÇÃO DA
} BATATINHA (*). Geraldo B. BarReto e Olavo JosÉ Boock. Em face do crescente interêsse do emprêgo da irrigação na cultura da batatinha no Estado de São Paulo, o Instituto Agronômico realizou ensaios preliminares sôbre êsse assunto durante três anos consecutivos (1952-1954).

Essses ensaios visaram determinar preliminarmente o efeito da irrigação na produção, tanto em presença como em ausência de adubações.

As adubações foram nos sulcos, nas mesmas datas de plantio, bem incorporadas à terra para evitar o contacto direto dos adubos com as batatas-semente e na base de 80 quilos de nitrogênio, 120 quilos de fósforo e 60 quilos de potássio por hectare, sob as formas, respectivamente, de sulfato de amônio, superfosfato e sulfato de potássio.

Um dos objetivos do ensaio era estabelecer, para o tipo de solo em estudo, o intervalo a ser observado entre duas irrigações consecutivas. O sistema de irrigação foi o de infiltração, sendo feita a aplicação de água nos sulcos entre as linhas de plantas. Cheio de água um sulco passava-se para o seguinte até completar a irrigação do canteiro. Medida essa quantidade de água por meio de um vertedor triangular de paredes delgadas, ângulo de $90^{\circ}$, verificou-se ser em média $37 \mathrm{~mm}$.

A aplicação de água foi feita sempre que as fôlhas das plantas apresentavam-se murchas e o solo sêco, demonstrando assim a necessidade da irrigação.

O terreno utilizado, de natureza argilo-silicosa, côr pardacenta, localizado na Estação Experimental de Monte Alegre do Sul, apresentava as seguintes características físicas e químicas, para a camada de $0,30 \mathrm{~m}$ : teores médios de matéria orgânica, de nitrogênio total, de óxido de cálcio e de acidez. O resultado da análise foi o seguinte:

Areia grossa . . . . . . . . . . 26 26,6

Limo . . . . . . . . . . . . . . . 58,6

Argila . . . . . . . . . . . . . 14,3

Umidade de murchamento . . . . . . . . 11,3

Umidade equivalente . . . . . . . . . 20,0

Matéria orgânica $(\mathrm{g}) \ldots \ldots \ldots \ldots$. . . . .

Nitrogênio total $(\mathrm{N}) \ldots \ldots \ldots$. . . . . 0,10

Fósforo $\left(\mathrm{PO}_{4}^{---} \mathrm{me}\right) \ldots \ldots \ldots . \ldots . \ldots 0,93$

Cálcio $\left(\mathrm{Ca}^{++} \mathrm{me}\right) \ldots \ldots \ldots \ldots . \ldots 2,94$

Potássio $\left(\mathrm{K}^{+} \mathrm{me}\right) \ldots \ldots \ldots, \ldots \ldots, 42$

(*) Recebida para publicação em 30 de outubro de 1957 . 
Os tratamentos empregados, em número de 16 , foram os seguintes: adubação nitrogenada, com e sem irrigação; adubação fosfatada, com e sem irrigação; adubação potássica, com e sem irrigação; adubação nitrogenada e fosfatada, com e sem irrigação; adubação nitrogenada e potássica, com e sem irrigação; adubação fosfatada e potássica, com e sem irrigação; adubação completa (NPK), com e sem irrigação e testemunha sem adubação, com e sem irrigação.

O delineamento do ensaio foi o de blocos ao acaso. Plantou-se a variedade Konsuragis (Solanum tuberosum L.), em 17-3-52 no primeiro ano, em 8-5-53 no segundo e em 12-5-54 no terceiro ano do ensaio. As colheitas foram feitas decorridos aproximadamente 105 dias do plantio, tendo sido calculada a produção na base de quilos por hectare.

Resultados - Embora os ensaios tenham sido prejudicados por chuvas extemporâneas, que encharcaram o terreno logo após o plantio no primeiro ano, pela ocorrência de geadas no segundo arıo, e pela má germinação das batatas-semente no terceiro ano, ainda assim foi possível obter informações valiosas sôbre o comportamento da irrigação no chamado período "das sêcas", ou seja, no período compreendido entre abril e agôsto.

No quadro 1 apresentamos os acréscimos porcentuais de produção de tubérculos, dos diferentes tratamentos.

QUADRo 1.-Aumentos porcentuais de produção de tubérculos de batatinha, de lotes irrigados sôbre nảo irrigados

\begin{tabular}{|c|c|c|c|c|}
\hline \multirow{2}{*}{ TRATAMENTOS } & \multicolumn{4}{|c|}{ A $\quad N \quad O \quad S$} \\
\hline & 1952 & 1953 & 1954 & Média \\
\hline & $\%$ & $\%$ & $\%$ & $\%$ \\
\hline Sem adubo $\ldots \ldots \ldots \ldots$ & 360,0 & 37,0 & 356,0 & 226,0 \\
\hline Com adubação nitrogenada (*) & 176,0 & 26,0 & 98,0 & 100,0 \\
\hline Com adubação fosfatada $(*) \ldots$ & 174,0 & 30,6 & 140,0 & 114,8 \\
\hline Com adubação potássica $(*, \ldots \ldots$ & 175,0 & 19,6 & 100,0 & 98,2 \\
\hline Com adubaçẫo completa . . . . & 216,0 & 22,3 & 105,0 & 114,4 \\
\hline
\end{tabular}

(*) Neste quadra foram grupados todos os tratamenios contendo adubos azotados. adubos fosfatados e adubos potássicos.

Conclusões - As conclusões do ensaio foram as seguintes:

a) as produções de modo geral foram baixas, devido aos fatôres enumerados, porém observou-se um aumento médio, nos três anos, de $226 \%$ entre a testemunha irrigada e a sem irrigação, a 
favor da primeira; diante do aumento de produção atribuído à irrigação julgamos não haver dúvidas sôbre as vantagens econômicas da mesma;

b) ainda que em menor grau que a irrigação, o fósforo contribuiu também para o aumento da produção, seguindo-se, em ordem decrescente, o nitrogênio e o potássio;

c) observou-se que para o tipo de solo utilizado as irrigações deverão ser efetuadas a intervalos de sete dias, no máximo, pois a partir daí as plantas começam a manifestar a necessidade de água. O curto intervalo entre as irrigações é devido, em parte, ao sistema radicular da batatinha, que é bastante superficial, e também ao sistema de cultivo em camalhões, o qual concorre para aumentar a perda de água por evaporação em virtude de exposição de maior superfície de solo. SEÇÃo dE CONSERVAÇ̃̃o do SOlo E SEÇÃo DE Raízes e TubÉrculos, Instituto Agronômico do Estado de SÃo PAULO.

\section{PRELIMINARY EXPERIMENTS WITH POTATO IRRIGATION}

\section{S U M M A R Y}

The purpose of this preliminary test was to study the effect of irrigation in the yield of potato during the dry season (April to August), in presence or absence of different kinds of fertilizers.

Extemporaneous rains and frost damaged the tests resulting in low production. Nevertheless it was possible to draw out valuable informations.

On the three-year period of the experiments the average increase in yield in the unfertilized plots was of about $226 \%$ in favor of the irrigated ones.

Following the irrigation in importance phosphorus contributed to increase the yield of potato tubers. Nitrogen and potassium in spite of yield increase, were less important.

The results show that about seven days is the best interval between irrigations for the soil studied, a silt loam soil, located at the Agricultural Experiment Station, at Monte Alegre do Sul. 